\title{
THE ROLE OF THE STUDY OF CONDITIONS AND DIRECTIONS OF SPATIAL DEVELOPMENT OF THE COMMUNE IN THE GROWTH OF DEVELOPERS' ACTIVITY BASED ON THE ŁÓDŹ EXAMPLE
}

\author{
Agata Antczak-Stępniak \\ Department of Investment and Real Estate \\ University of Łódź \\ e-mail:agata.antczak@uni.lodz.pl
}

\begin{abstract}
The importance of local plans for developers and negative consequences of issuing a large number of decisions on building conditions are usually discussed in literature, with the role of the study of conditions and directions of the spatial development of the commune somewhat diminished in this respect. The question therefore arises whether the study itself is important for the growth of developers' activity and, if so, whether its provisions are adhered to.

Therefore, the purpose of this article is to assess the impact of the study of conditions and directions of spatial development of the commune on developers' activity based on the example of Łódź. The author formulates a hypothesis that, from the point of view of developers' activity, it is a document of little importance, because its decisions are not abided by entities issuing BC decisions. To achieve the assumed goal, the following research methods were used: desk research analyzing the studies of conditions and directions of the spatial development of Łódź from 2010 and 2018, as well as gathering information on development investments from various online sources, and a comparative analysis of the location of development investments in the context of both mentioned documents.
\end{abstract}

Key words: residential market, development activity, spatial planning.

JEL Classification: $R 31, O 21$.

Citation: Antczak-Stępniak, A. (2020). The role of the study of conditions and directions of spatial development of the commune in the growth of developers' activity based on the Eódź example. Real Estate Management and Valuation, 28(3), 65-76.

DOI: https://doi.org/10.1515/remav-2020-0024

\section{Introduction}

There are many definitions of spatial planning (Cullingworth \& Nadin, 2006, p. 91; Saey, 2002, p. 95122; Nichersu \& Iacoboaea, 2011, p. 67-68; Acheampong, 2018, p. 11). However, by summarizing them all, it can be assumed that spatial planning is a key instrument of medium and long-term management of spatial development, promoting the rational use of space. The purpose of planning is to balance demand for investment areas with socio-economic needs (Stead \& Nadin 2008, p. 1). Rational spatial planning in a given area ensures investment stability and improves investor confidence in the authorities of a given commune, facilitates the process of making investment decisions, generates demand for real estate important for the commune's development, guarantees the economically rational distribution of functions in the city, and improves the quality of space, which, in turn, increases the value of real estate, etc. (Krajewska et al., 2014, p. 52-66). Some studies, however, indicate that spatial planning has a negative impact on certain types of economic activity. Production and warehouse activity can be indicated as examples of this. These activities require significant space, while local plans effectively limit the supply of land that can be used for these functions (Ploegmakers 
et al., 2018, pp. 3253-3254). In Poland, spatial planning is bottom-up, i.e. the municipality is the level with planning authority. All solutions adopted at a higher level must later be reflected in documents prepared by the municipality. The Act of 27 March 2003 on spatial planning and development introduced two basic planning documents prepared at the municipal level:

- study of conditions and directions of spatial development of the commune (the study), which is obligatory and is prepared for the entire commune, and

- local spatial development plan of the commune (local plan), which is optional, but is an act of local law. In the absence of a local plan, it is necessary to apply for a decision on building conditions (Act of 27 March 2003...).

Pluta (2016), after Izdebski et al. (2007) and Ścibor (2007), recalls the weaknesses of the Polish spatial planning system that prevents rational and effective shaping of space. Among these weaknesses, the following could be included: no strong correlation between spatial planning and socio-economic and investment planning, and too far-reaching powers of the relevant authorities to make planning decisions. What is more, studies of conditions and directions of spatial development of the commune is not local legal acts, which means that their provisions are not binding; decisions on building conditions are not consulted with the local community, the number of local plans is small on a national scale, and the existing ones usually concern recreational, green, and protected areas, suburbs, or communication routes. In turn, decisions on building conditions contribute to the dispersion of housing. In addition, it is not specified in relation to areas intended for development plans for buildings what costs will have to be incurred to provide them with the appropriate infrastructure. The range of symbols for individual functions is very narrow, which means that municipalities must enter their own designations. Therefore, this does not ensure the comparability of the documents in question between individual territorial units. These documents are rarely introduced into spatial information systems, which would significantly facilitate decision-making processes for investors (see: Pluta, 2016, pp. 162-163). The literature also indicates the fact that the use of land for housing does not guarantee the demand for flats that will actually be realized there (Yakob et al., 2012, p. 581). This observation draws attention to the importance of social participation in the process of adopting any planning documents.

The topic of the impact of local plans and decisions on building conditions on the process of urban development and the investment process is raised by many Polish scientific publications (Raźniak \& Grochal, 2014, pp. 98-109; Gorzym-Wilkowski, 2016, pp. 223-232; Hajduk \& Baran, 2013, pp. 117-129). However, the role of the study in the growth of developers' activity seems to be underestimated in these publications. That is why this document became the subject of the author's reflections.

Therefore, the purpose of this article is to assess the impact of the study of conditions and directions of spatial development of the commune on developers' activity based on the example of Łódź. The author puts forward a hypothesis that, from the point of view of developers' activity, it is a document of little significance, and its provisions are not observed. To achieve the assumed goal and verify the hypothesis in this article, the analysis of literature on the subject, the Studies of conditions and directions of spatial development of the city of Eódź from 2010 and 2018, and data on the location of developers' investments in relation to the functional and spatial structure specified in the Studies were used.

\section{The study of conditions and directions of spatial development as a source of information for developers}

The study of conditions and directions of spatial development of the commune is a document defining its spatial policy. In the part devoted to development conditions, it contains information on the current use of land and utilities, the state of spatial order, the environment, the state of cultural heritage and monuments, as well as modern cultural goods, conditions and the quality of life of the residents, the needs and possibilities of the commune's development, the legal status of land, the occurrence of objects and protected areas, the occurrence of areas of natural geological hazards, documented mineral deposits and groundwater resources, the state of communication systems and technical infrastructure, and tasks serving the implementation of supra-local public purposes, etc. (Act of 27 March 2003...). However, what is particularly important from the point of view of developers' activity are development directions. If the developer already owns the property, and the study indicates that it should be built over with industrial buildings or that these are green areas, then it may turn out that it will not be possible to obtain decisions on building conditions for this location 
allowing for the implementation of housing projects. However, as practice shows, such decisions are sometimes issued despite everything. In relation to development directions, the study of conditions and directions of spatial development of the commune defines directions of changes in the spatial structure of the commune and land use, directions and indicators regarding land use, including areas intended for development and land excluded from development, areas and principles of environmental protection and its resources, nature protection, landscape protection, cultural heritage protection, directions of communication systems and technical infrastructure development, areas where public purpose investments of local and supra-local significance will be located, areas for which it is obligatory to draw up a local spatial development plan, areas for which the municipality intends to draw up a local spatial development plan, directions and principles for shaping agricultural and forestry production space, areas of particular flood risk and areas of landslides, areas of monuments of extermination and their zone areas that need transformation, rehabilitation, reclamation or remediation, degraded areas, etc. (Act of March 27, 2003...).

The study of conditions and directions of spatial development of the commune is therefore the first document signaling information for property owners about potential functions that can be implemented on a given property and in its vicinity (Foryśs \& Putek-Szeląg, 2015, pp. 62-65). For this reason, this is the basic document that developers should pay attention to when looking for the right location for their project.

It would therefore seem, that the study should play a greater role in the spatial planning system, due to the fact that, having a holistic nature, it contains a vision of the city's development - how it should be managed to meet the needs of the population in an effective way, and at the same time ensure the rational use of limited land resources. It should therefore be a reference point for investors looking for real estate appropriate for achieving their goals. Local plans, in turn, are a tool for the implementation of the spatial policy enshrined in the study, therefore they only specify the conditions for the development of individual properties that the investor intends to transform (local plans must comply with the provisions of the study, decisions on building conditions do not) (Act of March 27, 2003...). This system would be extremely effective if all municipalities were $100 \%$ covered with local plans. Unfortunately, this is not the case in Poland.

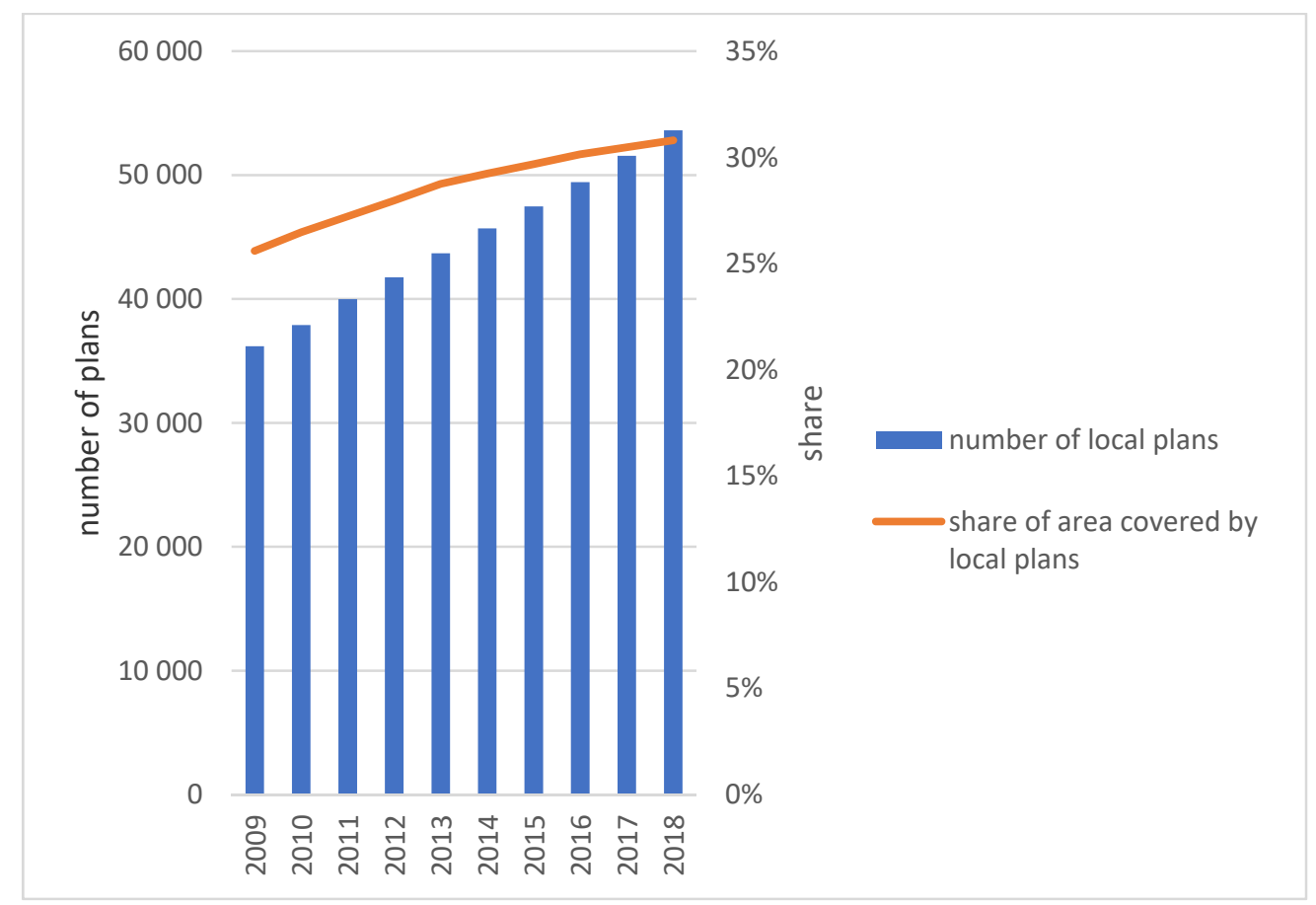

Fig. 1. The number of local plans and the share of the country's area covered by plans in 2009-2018. Source: own elaboration based on LDB.

According to the data presented in Figure 1, the number of local plans in Poland is increasing from year to year, but the pace of this growth seems relatively low. Over the period of nine years, nearly 17,500 local plans were adopted. Considering the data on the percentage of the country's area covered 
by plans, it can be clearly seen that these are rather plans covering small areas. Since 2009, this share has increased by only $5 \%$ and, in 2018 , it was $31 \%$. The low level of coverage with plans means the growing role of decisions on building conditions, which have become the rule in the Polish planning system, although the intention of the creators of the Act was for these decisions to be an exception. In addition, it is emphasized that, in practice, BC decisions are not always issued in accordance with the provisions of the studies. In fact, the Act on planning and spatial development is criticized due to its low rank, seeing as how, in the absence of local plans, it does not guarantee the implementation of the directions specified therein (Brzeziński, 2013, p. 106).

The above-presented theoretical considerations lead to the conclusion that in those cities where there are few local plans, the study is losing importance and developers and other investors are, in practice, responsible for developing the city, quite easily obtaining favorable BC decisions, uncritically issued by relevant authorities.

\section{Data and Methods}

In the empirical part of this article, the following research methods were used: desk research in the field of analysis of Studies of conditions and directions of the spatial development of Łódz from 2010 and 2018, as well as gathering information on development investments from various online sources, and a comparative analysis of the location of development investments in the context of both mentioned documents. The desk research method is based on the use of existing data: statistics and public summaries, official documents, results of social and marketing research, data and information available online, etc. Such data primarily helps to obtain a broad context of knowledge on a given topic, but also allows the researcher to collect and analyze data on a specific topic (Bednarowska, 2015, pp. 18-26). Comparative analysis allows us to collate and analyze similarities and differences between two or more objects. Thanks to this, attempts can be made to identify the cause-and-effect relationships of the studied phenomena (Bukhari, 2011).

The city of Łódź was adopted as the research area in this article. The reason for this is that Łódź is one of the voivodship cities with the lowest level of coverage with local plans, and thus characterized by a large number of decisions on building conditions issued, which, according to applicable law, do not have to take into account the study of conditions and directions of spatial development of the commune. Secondly, it is the city best recognized by the author, due to previous research conducted in the city.

The study was carried out in five stages:

1) analysis of determinations in the Studies of conditions and directions of the spatial development of Łódź from 2010 and 2018,

2) identification of developers' investments that were on sale in May 2019 (both during implementation and commissioned). Many of those projects were at the stage of initiation and concept preparation during the Study of 2010,

3) identification of areas in the Study of 2010 where developers' investments were carried out in 2019,

4) identification of areas in the Study of 2018 where developers' investments were carried out in 2019,

5) detailed comparative analysis of the location of individual development investments in the context of both Studies of conditions and directions of spatial development in the city of Łódz.

Information on investments on sale has been obtained from popular real estate market portals such as: rynekpierwotny.pl, noweinwestycje.pl, gratka.pl, otodom.pl and others, as well as websites of individual developers. The location of these investments in the context of the Studies from 2010 and 2018 was possible due to the introduction of their graphic attachments to the InterSIT (Municipal Area Information System), which allows for interactive location analysis.

\section{The importance of study conditions and directions of spatial development of the commune in the growth of developers' activity in Łódź - research results}

In the years 2002-2010, the spatial policy of the city of Łódź was conducted based on the Study of conditions and directions of spatial development in Łódz of 2002, i.e. created on the basis of the no longer binding Act on spatial planning in 1994. The entry into force of the Act on spatial planning and development in July 2003 meant the necessity of taking further actions aimed at adapting the Study to the provisions of the new Act. The NIK audit, carried out in 2006, however, pointed to numerous 
problems related to, among others, the lack of design practice and appropriately qualified human resources (Information on the results of the audit... 2011, p. 7), which contributed to the extension of its preparation time to 8 years. In addition, at the stage of public consultations in 2010, public protests emerged regarding the adopted directions of the city's development. The functional structure of the city presented in the Study seemed to lack coherence. Areas of Łódź focused on the development of single-family housing were located almost everywhere: in the central parts of the city (this resulted from the already existing buildings), among multi-family housing estates, in the immediate vicinity of industrial and warehouse areas, and in green or agricultural areas (Study of conditions and directions of development ... 2010). There were moreover far too many of them, more than required by the needs of a city characterized by an outflow of the population. This approach favored the spread of the city, which also contributed to the increase in the costs of maintaining the technical infrastructure in Łódź.

The growing interest in sustainable development and the growing awareness of the city's authorities contributed to undertaking work in 2013 on a new Study, which was adopted in 2018. The new Study provides for the density of urbanized areas, taking into account the development rights granted so far (Justification under Article 42, point 2...). This means that no conflicts arising from the non-compliance of issued building condition decisions with the provisions of the Study should occur, or if they do, they should be significantly reduced. Unfortunately, the conducted research still indicates that the provisions of the Study are not respected by the entities issuing the above-mentioned decisions also in the context of developers' activity conducted in Łódź.

4.1. Changes in the designations as well as functional and spatial structure of the Studies from 2010 and 2018

Reflections on the role of the Study of conditions and directions of spatial development of Łódź in the growth of developers' activity should begin with discussing the changes that were introduced in 2018 compared to the document in force since 2010. Particular attention should be paid to two issues, namely: the change of designations in those Studies that have been clarified, and the location and size of individual functional areas in Łódź.

Table 1

Changes of the designations in the Study of conditions and directions of spatial development of the city of Łódź from 2010 and 2018

\begin{tabular}{|c|c|c|c|}
\hline \multicolumn{2}{|c|}{ The Study from 2010} & \multicolumn{2}{|c|}{ The Study from 2018} \\
\hline Symbol & Description & Symbol & Description \\
\hline \multirow[t]{7}{*}{ SZ } & \multirow{7}{*}{ Downtown buildings } & \multirow{7}{*}{$\begin{array}{l}\text { W1a, } \\
\text { W1b, } \\
\text { W2a, } \\
\text { W2b, } \\
\text { W3b, } \\
\text { W3c }\end{array}$} & Multifunctional areas \\
\hline & & & W1a (multi-family and services) \\
\hline & & & $\begin{array}{l}\text { W1b (multi-family, service }+ \text { with } \\
\text { restrictions: industry, single-family } \\
\text { housing and commerce) }\end{array}$ \\
\hline & & & $\begin{array}{l}\text { W2b (multi-family, service }+ \text { with } \\
\text { restrictions: industry, single-family } \\
\text { housing and commerce) }\end{array}$ \\
\hline & & & $\begin{array}{l}\text { W2b (multi-family, service }+ \text { with } \\
\text { restrictions: industry and commerce) }\end{array}$ \\
\hline & & & $\begin{array}{l}\text { W3b (multi-family, service }+ \text { with } \\
\text { restrictions: industry, single-family } \\
\text { housing and commerce) }\end{array}$ \\
\hline & & & $\begin{array}{l}\text { W3c (multi-family, service }+ \text { with } \\
\text { restrictions: commerce) }\end{array}$ \\
\hline UC1 & $\begin{array}{l}\text { The functional } \\
\text { Piotrkowska Street }\end{array}$ & W3a & $\begin{array}{l}\text { Service buildings along the } \mathrm{W}-\mathrm{Z} \text { route } \\
\text { (multi-family, service + with restrictions: } \\
\text { commerce) }\end{array}$ \\
\hline UC2 & $\begin{array}{l}\text { Areas of the modern } \mathrm{W}-\mathrm{Z} \text { service } \\
\text { axis }\end{array}$ & WZ & $\begin{array}{l}\text { Multifunctional buildings (service, multi- } \\
\text { family and single-family housing }+ \text { with } \\
\text { restrictions: production and commerce) }\end{array}$ \\
\hline UC3 & Areas of the implemented New & M1 & Areas of large housing complexes (multi- \\
\hline
\end{tabular}




\section{$\$$ sciendo}

\begin{tabular}{|c|c|c|}
\hline $\mathrm{UC3}^{*}$ & $\begin{array}{l}\text { Center of Łódź program } \\
{ }^{*} \text { With large commerce area }\end{array}$ & $\begin{array}{l}\text { family and service buildings }+ \text { with } \\
\text { restrictions: single-family housing) }\end{array}$ \\
\hline UC4 & $\begin{array}{l}\text { Intersection areas of the main } \mathbf{M 2} \\
\text { communication axes }\end{array}$ & $\begin{array}{l}\text { Single-family and multi-family low } \\
\text { development areas (single-family, } \\
\text { service, multi-family up to } 8 \text { apartments } \\
\text { + with restrictions: commerce) }\end{array}$ \\
\hline $\begin{array}{l}\text { UC } \\
\text { UC }^{*}\end{array}$ & $\begin{array}{l}\text { Areas of service concentration } \\
{ }^{*} \text { With large commerce area }\end{array}$ & $\begin{array}{l}\text { Single-family housing (single-family, } \\
\text { service }+ \text { with restrictions: multi-family } \\
\text { and commerce) }\end{array}$ \\
\hline MW & $\begin{array}{l}\text { Areas with a majority of multi- M4 } \\
\text { family housing }\end{array}$ & $\begin{array}{l}\text { Single-family housing on large plots } \\
\text { (single-family, service + with restrictions: } \\
\text { commerce) }\end{array}$ \\
\hline MN & $\begin{array}{l}\text { Areas with a predominance of } \mathbf{P M} \\
\text { single-family housing }\end{array}$ & $\begin{array}{l}\text { Housing development in street systems } \\
\text { (farm, single-family, service buildings, } \\
\text { agricultural production }+ \text { with } \\
\text { restrictions: commerce) }\end{array}$ \\
\hline MNU & $\begin{array}{l}\text { Areas with a predominance of } \\
\text { single-family } \mathrm{U} \\
\text { buildings }\end{array}$ & $\begin{array}{l}\text { Service buildings (broadly understood } \\
\text { services + with restrictions: production, } \\
\text { multi-family, single-family housing and } \\
\text { commerce) }\end{array}$ \\
\hline MN1 & $\begin{array}{l}\text { Single-family and service } \mathbf{O} \\
\text { buildings, transformed from rural } \\
\text { areas }\end{array}$ & $\begin{array}{l}\text { Environmentally active areas used for } \\
\text { agriculture (agricultural, recreational and } \\
\text { leisure areas, allotments, mine areas + } \\
\text { with restrictions: agricultural production } \\
\text { and housing development) }\end{array}$ \\
\hline MR & Residential development areas & $\begin{array}{l}\text { Green areas arranged in the urban zone } \\
\text { (green areas, recreation, leisure and } \\
\text { sports + with restrictions: commerce and } \\
\text { allotments) }\end{array}$ \\
\hline $\mathbf{Z L}$ & Forest green areas & $\begin{array}{l}\text { allotment areas, individual recreation, } \\
\text { greenery + with restrictions: recreation, } \\
\text { leisure and sport facilities }\end{array}$ \\
\hline $\mathbf{Z P}$ & $\begin{array}{l}\text { Green areas arranged with a } \mathbf{R W} \\
\text { service program }\end{array}$ & Recreation areas \\
\hline ZD & Allotments & \\
\hline ZN & $\begin{array}{l}\text { Natural green areas and river } \\
\text { valleys }\end{array}$ & \\
\hline $\mathbf{R P}$ & Agricultural land & \\
\hline UM & Areas of metropolitan services & \\
\hline
\end{tabular}

Source: own elaboration based on the Study of conditions and directions of spatial development of the city of Łódź from 2010 and 2018.

It should be emphasized that the analysis of the designations covers only those areas where developers' investments were carried out or completed in May 2019. The former areas of downtown buildings (SZ) were replaced by multifunctional areas (W), which were, however, divided into smaller parts, introducing restrictions regarding the implementation of specific types of buildings for their individual subcategories (see: Study of conditions and directions..., 2018, pp. 44-69). Currently, this category also includes the former areas of the functional area of Piotrkowska Street, the New Center of Łódź, and areas along the main communication axes, which slightly increases the transparency of the Study, due to the smaller number of Main categories. Such an action seems to be beneficial for the future development of the city in the context of spatial order. From the point of view of developers' activity, however, this may constitute a certain difficulty in accessing individual properties (unless decisions on building conditions are still issued regardless of the provisions of the study). In some cases, the changes introduced in the area designations are insignificant, e.g. the former ZN and RP areas have been combined into naturally active $(\mathrm{O})$ areas, although they seem to have been more 


\section{$\$$ sciendo}

specific. Quite basic and at the same time positive, according to the author, changes occurred in relation to single-family housing. In the Study from 2010, the areas with a predominance of singlefamily housing as well as the predominance of single-family and service buildings were distinguished, which created quite a lot of interpretative freedom, and, in fact, enabled a fairly free implementation of multi-family housing in these areas. In the Study from 2018, areas where multifamily housing can be implemented among single-family housing are more precisely distinguished, but with the restrictions that such a building cannot include more than 8 apartments (M2) or it needs to be constructed as an addition to existing buildings (M3). In other areas, multi-family housing cannot be built.

Quite significant changes can also be observed in relation to the size and distribution of individual functions within the city.

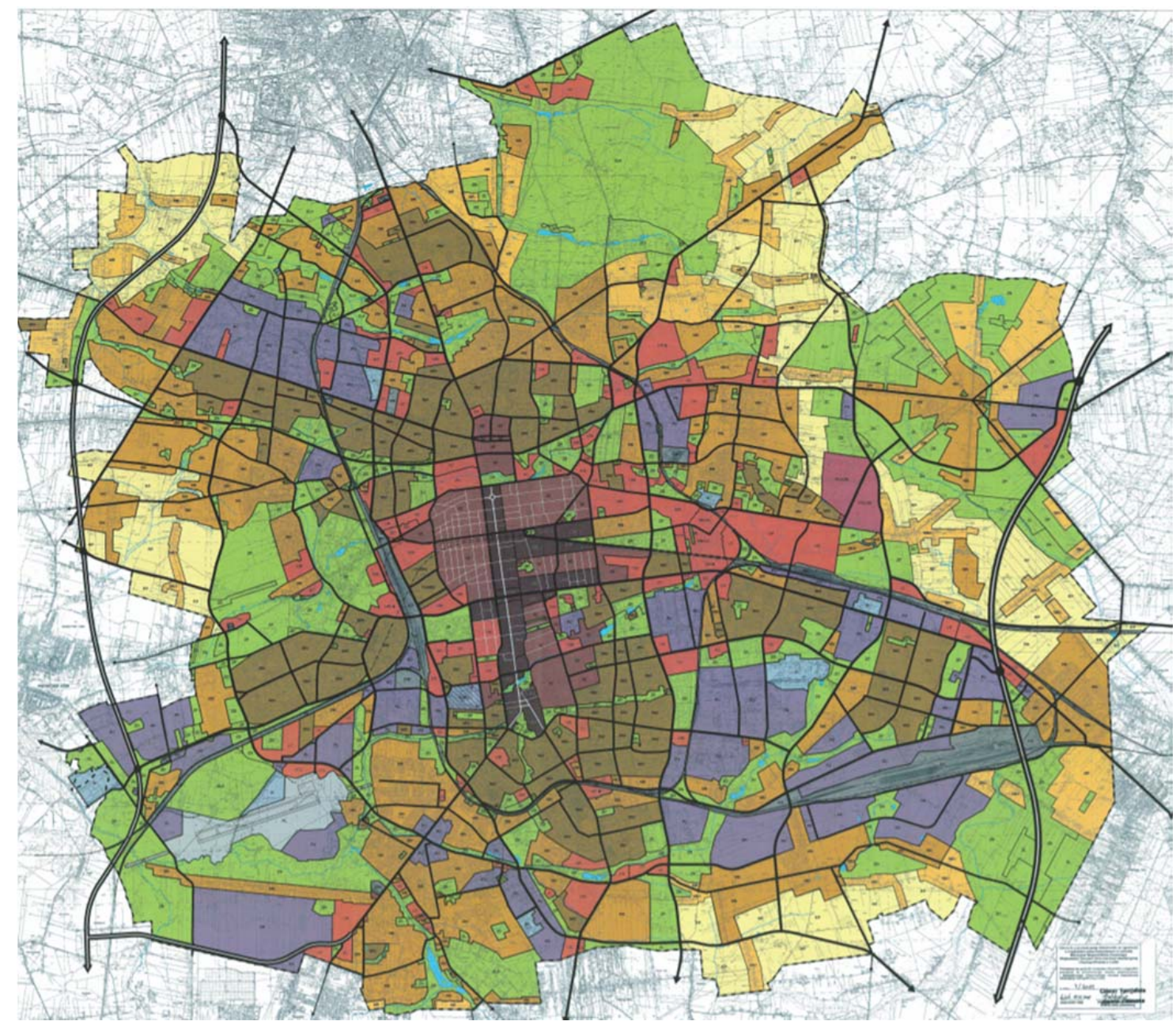

Map 1. Functional and spatial units according to the 2010 Study. Source: Study of conditions and directions of spatial development in the city of Łódź from 2010.

The basic difference that can be observed in the graphical appendices to the Studies presented above concerns the area of undeveloped areas. In Map 2, there are many more such areas than in Map 1. Unfortunately, this is not only the effect of reducing the area designated for housing but also replacing the areas indicated in the 2010 Study as green areas, with naturally active areas which, however, with some restrictions can be used for housing or recreation and leisure. However, this only applies to supplementing existing buildings, most often located along existing communication routes, which should contribute to the development of more compact buildings.

\subsection{Location of developers' investments within individual functional areas of Łódź}

To determine whether the Study of conditions and directions of spatial development in Eódź has an impact on the growth of developers' activity in this city, the location of developers' investments included in 


\section{S sciendo}

the sale offer in May 2019 was analyzed in the context of the results of both Studies. In total, 124 developers' investments were analyzed.

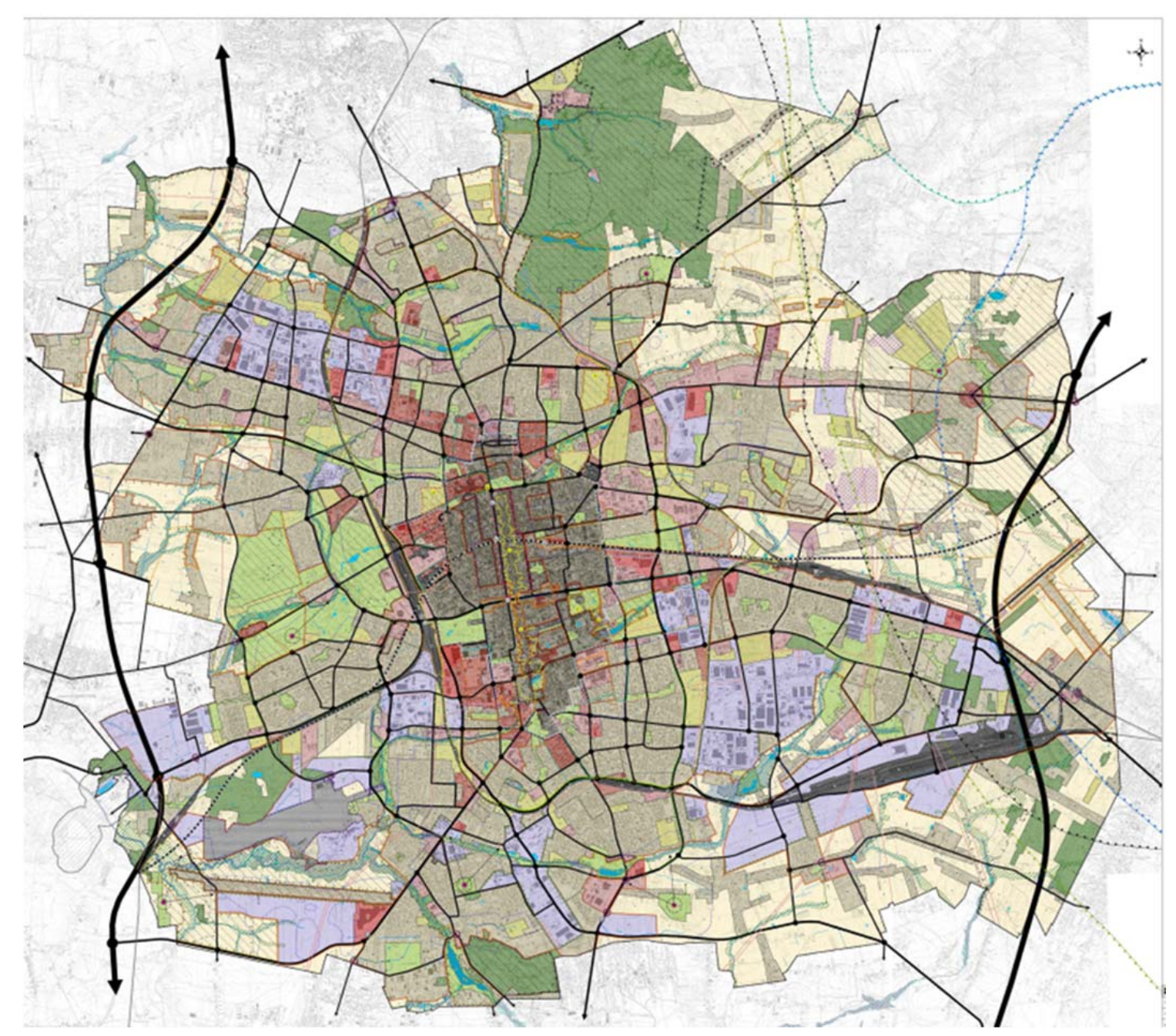

Map 2. Functional and spatial units according to the 2018 Study. Source: Study of conditions and directions of spatial development of the city of Łódź from 2018.

Table 2

Structure of developers' investments implemented in May 2019 in relation to the directions of spatial development specified in the Studies form 2010 and 2018

\begin{tabular}{llll}
\hline $\begin{array}{l}\text { The Study from 2010 } \\
\begin{array}{l}\text { Designation of } \\
\text { directions of spatial } \\
\text { development }\end{array}\end{array}$ & $\begin{array}{l}\text { Number of } \\
\text { investments (stages) }\end{array}$ & $\begin{array}{l}\text { The Study from 2018 } \\
\text { Designation of } \\
\text { directions of spatial } \\
\text { development }\end{array}$ & $\begin{array}{l}\text { Number of } \\
\text { investments (stages) }\end{array}$ \\
\hline MW & 43 & M1 & 39 \\
\hline MN/MN1 & 30 & W3b & 25 \\
\hline UC2 & 9 & WZ & 10 \\
\hline UC & 8 & U & 3 \\
\hline SZ & 15 & M2 & 8 \\
\hline UC1 & 4 & M3 & 18 \\
\hline ZD & 4 & M4 & 1 \\
\hline UM & 3 & PM & 5 \\
\hline UC3 & 2 & O & 4 \\
\hline MR & 1 & W3c & 2 \\
\hline ZN & 2 & W2a & 4 \\
\hline
\end{tabular}




\section{S sciendo}

\begin{tabular}{llll}
\hline ZP & 1 & W1a & 1 \\
\hline RP & 2 & W2b & 2 \\
\hline & & RW & 1 \\
\hline & & D & 1 \\
\hline Total & 124 & Total & 124 \\
\hline
\end{tabular}

Source: own elaboration.

The above-presented comparison shows that the development directions of some areas have changed. The same development projects were subject to consideration. According to the no longer binding Study from 2010, there were 43 development projects in the multi-family housing areas in May 2019, while in the M1 area (which, as previously agreed, means almost the same) there are already 39 such investments. This means that 4 locations in the 2018 Study have changed their function. Interestingly, the multi-functional downtown area has been increased. 38 investments were located in the former SZ, UC, UC1, UC2, UC3 areas, while according to the new designations (W) in multifunctional areas, including WZ, there are 44 investments. Although the fact that the area of single-family housing as a direction of city development was reduced in favor of active nature areas is a positive phenomenon, several investments have unfortunately already received $\mathrm{BC}$ decisions in the meantime ,and ultimately 4 investments are located in such areas. According to the Study from 2010, 4 investments were located in green areas and areas designated for arable crops, with 6 such investments already present in areas with similar functions according to the Study from 2018.

The detailed location analysis presented in Table 3 allowed us to demonstrate investments carried out in places not compliant with the directions specified in both Studies.

Table 3

Location of developers' projects from May 2019 in the context of development directions included in the Studies from 2010 and 2018

\begin{tabular}{llll}
\hline & $\begin{array}{l}\text { Type of } \\
\text { buildings }\end{array}$ & $\begin{array}{l}\text { Study } \\
\text { No }\end{array}$ & $\begin{array}{l}\text { The } \\
\text { Study } \\
2010\end{array}$ \\
\hline $\mathbf{1}$ & Multi-family & MW & M1 \\
\hline $\mathbf{2}$ & Multi-family & UC2 & W3b \\
\hline $\mathbf{3}$ & Multi-family & MW & M1 \\
\hline $\mathbf{4}$ & Multi-family & MW & M1 \\
\hline $\mathbf{5}$ & Multi-family & MN & M1 \\
\hline $\mathbf{6}$ & Multi-family & MN & M1 \\
\hline $\mathbf{7}$ & Multi-family & MW & WZ3 \\
\hline $\mathbf{8}$ & Multi-family & MW & U \\
\hline $\mathbf{9}$ & Multi-family & UC & M1 \\
\hline $\mathbf{1 0}$ & Multi-family & SZ & W3b \\
\hline $\mathbf{1 1}$ & Multi-family & UC1 & W3b \\
\hline $\mathbf{1 2}$ & Multi-family & UC & W3b \\
\hline $\mathbf{1 3}$ & Multi-family & UC & W3b \\
\hline $\mathbf{1 4}$ & Multi-family & UC & W3b \\
\hline $\mathbf{1 5}$ & Multi-family & ZD & M1 \\
\hline $\mathbf{1 6}$ & Multi-family & ZD & M1 \\
\hline $\mathbf{1 7}$ & Multi-family & ZD & M1 \\
\hline $\mathbf{1 8}$ & Multi-family & MN & M3 \\
\hline $\mathbf{1 9}$ & Multi-family & MW & M1 \\
\hline $\mathbf{2 0}$ & Multi-family & MW & M1 \\
\hline $\mathbf{2 1}$ & Multi-family & MW & M2 \\
\hline $\mathbf{2 2}$ & Multi-family & MW & M2 \\
\hline $\mathbf{2 3}$ & Multi-family & MW & M1 \\
\hline & & & \\
\hline
\end{tabular}

\begin{tabular}{llll}
\hline $\mathbf{2 4}$ & Multi-family & UC2 & W3a/W3b \\
\hline $\mathbf{2 5}$ & Multi-family & UC2 & W3a/W3b \\
\hline $\mathbf{2 6}$ & Multi-family & UC2 & W3a/W3b \\
\hline $\mathbf{2 7}$ & Multi-family & UM & M1 \\
\hline $\mathbf{2 9}$ & Multi-family & UC & WZ2 \\
\hline $\mathbf{3 0}$ & Single-family & MN & M3 \\
\hline $\mathbf{3 1}$ & Multi-family & MN & M3 \\
\hline $\mathbf{3 2}$ & Multi-family & MW & M1 \\
\hline $\mathbf{3 3}$ & Multi-family & SZ & W3b \\
\hline $\mathbf{3 4}$ & Multi-family & SZ & W3b \\
\hline $\mathbf{3 5}$ & Multi-family & UC3 & W3c \\
\hline $\mathbf{3 6}$ & Multi-family & UC2 & W3b \\
\hline $\mathbf{3 7}$ & Multi-family & UC2 & W3b \\
\hline $\mathbf{3 8}$ & Multi-family & UC2 & W3b \\
\hline $\mathbf{3 9}$ & Multi-family & SZ & W3b \\
\hline $\mathbf{4 0}$ & Multi-family & MW & M1 \\
\hline $\mathbf{4 1}$ & Multi-family & MW & M1 \\
\hline $\mathbf{4 2}$ & Multi-family & MW & M1 \\
\hline $\mathbf{4 3}$ & Multi-family & UC1 & W2b \\
\hline $\mathbf{4 4}$ & Multi-family & MW & M1 \\
\hline $\mathbf{4 5}$ & Multi-family & MW & M1 \\
\hline & Detached single- & MR & M2/M4 \\
\hline $\mathbf{4 6}$ & family & UM & W3b \\
\hline $\mathbf{4 7}$ & Multi-family & UM & W3b \\
\hline $\mathbf{4 8}$ & Multi-family & SZ & \\
\hline & & & UC \\
\hline
\end{tabular}




\begin{tabular}{|c|c|c|c|}
\hline 49 & Multi-family & MW & WZ3 \\
\hline 50 & Multi-family & SZ & W3b \\
\hline 51 & Multi-family & MW & M1 \\
\hline 52 & Multi-family & MW & M1 \\
\hline 53 & Multi-family & UM & W3b \\
\hline 54 & Multi-family & UC & $\mathrm{U}$ \\
\hline 55 & Multi-family & MW & M1 \\
\hline 56 & Multi-family & MW & M1 \\
\hline 57 & $\begin{array}{l}\text { Detached single- } \\
\text { family }\end{array}$ & $\mathrm{MN}$ & M3 \\
\hline 58 & Multi-family & MW & M1 \\
\hline 59 & Multi-family & MW & M1 \\
\hline 60 & Multi-family & MW & M1 \\
\hline 61 & Multi-family & MW & M1 \\
\hline 62 & Multi-family & SZ & W3b \\
\hline 63 & Multi-family & MW & WZ2 \\
\hline 64 & Multi-family & $\mathrm{MN}$ & $\mathrm{O}$ \\
\hline 65 & Multi-family & SZ & M1 \\
\hline 66 & Multi-family & MW & M1 \\
\hline 67 & Multi-family & UC1 & W2a \\
\hline 68 & Multi-family & SZ & W2a \\
\hline 69 & Multi-family & $\mathrm{MN}$ & M3 \\
\hline 70 & Multi-family & MN & M3 \\
\hline 71 & Multi-family & UC3 & W3c \\
\hline 72 & Multi-family & MN & $\mathrm{U}$ \\
\hline 73 & Multi-family & MW & M1 \\
\hline 74 & Multi-family & MW & M1 \\
\hline 75 & Multi-family & MW & M1 \\
\hline 76 & Multi-family & MW & M1 \\
\hline 77 & Multi-family & MW & M1 \\
\hline 78 & Multi-family & MW & WZ2 \\
\hline 79 & Multi-family & MW & WZ2 \\
\hline 80 & Multi-family & MW & WZ2 \\
\hline 81 & $\begin{array}{l}\text { Detached single- } \\
\text { family }\end{array}$ & $\mathrm{MN}$ & M3 \\
\hline 82 & $\begin{array}{l}\text { Detached single- } \\
\text { family }\end{array}$ & MN1 & PM \\
\hline 83 & Multi-family & SZ & WZ1 \\
\hline 84 & Multi-family & $\mathrm{MN}$ & M2 \\
\hline 85 & Multi-family & ZD & $\mathrm{D}$ \\
\hline 86 & Multi-family & $\mathrm{ZN}$ & M3 \\
\hline 87 & Multi-family & SZ & W3b \\
\hline 88 & Multi-family & $\mathrm{MN}$ & M2 \\
\hline 89 & Semi-detached & MN & M3 \\
\hline
\end{tabular}

\begin{tabular}{|c|c|c|c|}
\hline & single-family & & \\
\hline 90 & $\begin{array}{l}\text { Semi-detached } \\
\text { single-family }\end{array}$ & MN & M3 \\
\hline 91 & $\begin{array}{l}\text { Detached single- } \\
\text { family }\end{array}$ & $\mathrm{MN}$ & PM \\
\hline 92 & $\begin{array}{l}\text { Detached single- } \\
\text { family }\end{array}$ & $\mathrm{MN}$ & PM \\
\hline 93 & $\begin{array}{l}\text { Detached single- } \\
\text { family }\end{array}$ & $\mathrm{MN}$ & M3 \\
\hline 94 & $\begin{array}{l}\text { Semi-detached } \\
\text { single-family }\end{array}$ & $\mathrm{ZN}$ & $\mathrm{O}$ \\
\hline 95 & $\begin{array}{l}\text { Semi-detached } \\
\text { single-family }\end{array}$ & $\mathrm{MN}$ & PM \\
\hline 96 & Multi-family & $\mathrm{MN}$ & M3 \\
\hline 97 & Multi-family & $\mathrm{MN}$ & M1 \\
\hline 98 & Multi-family & MW & M1 \\
\hline 99 & Multi-family & MW & M1 \\
\hline 100 & Multi-family & SZ & W3b \\
\hline 101 & Multi-family & $\mathrm{MN}$ & M4 \\
\hline 102 & Multi-family & UC1 & W1a \\
\hline 103 & $\begin{array}{l}\text { Detached single- } \\
\text { family }\end{array}$ & $\mathrm{RP}$ & M3 \\
\hline 104 & Multi-family & UC2 & W3b \\
\hline 105 & Multi-family & $\mathrm{ZP}$ & RW \\
\hline 106 & Multi-family & $\mathrm{MN}$ & M3 \\
\hline 107 & Multi-family & UC2 & W2a \\
\hline 108 & Multi-family & SZ & W2a \\
\hline 109 & Multi-family & $\mathrm{MN}$ & M3 \\
\hline 110 & Multi-family & MW & W3b \\
\hline 111 & Multi-family & SZ & W3b \\
\hline 112 & Multi-family & SZ & WZ1 \\
\hline 113 & Multi-family & MW & M1 \\
\hline 114 & Multi-family & MW & M2 \\
\hline 115 & Multi-family & $\mathrm{UC}$ & WZ2 \\
\hline 116 & Multi-family & MW & M1 \\
\hline 117 & Multi-family & MW & M2 \\
\hline 118 & Single-family & $\mathrm{MN} / \mathrm{UC}$ & M3 \\
\hline 119 & Single-family & $\mathrm{RP}$ & $\mathrm{O}$ \\
\hline 120 & Single-family & $\mathrm{MN}$ & PM \\
\hline 121 & Multi-family & MW & M2 \\
\hline 122 & Single-family & $\mathrm{MN}$ & M3 \\
\hline 123 & Single-family & $\mathrm{MN}$ & M2 \\
\hline 124 & Single-family & $\mathrm{MN}$ & M3 \\
\hline
\end{tabular}

Note: highlighted areas mean significant changes in the directions of spatial development in Łódź and the way buildings are in conflict with their findings

Source: own elaboration.

Based on Table 3, several interesting conclusions can be made. First of all, some areas that had already been used by developers in some way for housing development, despite different findings of the Studies (decisions on building conditions were not always issued in accordance with the provisions of the study), were transformed. This applies, among others, to the areas along Falista St., which, 
according to the 2010 study, was located in the MN area - with a predominance of single-family housing, whereas currently, according to Study from 2018, these are already areas of large residential complexes. Secondly, an unfavorable change is that some green areas have unfortunately been transformed into residential areas. This was done because a housing investment was already being implemented there before the change of the Study. The most negative phenomenon observed based on this study is the implementation of housing projects in areas with a completely different function. Such investments were recorded in the number of 12 . They are related to the implementation of multifamily housing in areas specified in the Study from 2018 as service, single-family and low multi-family housing (up to 8 apartments), naturally active and agriculturally used, allotment areas, single-family housing in street layout areas, etc. Such activity indicates a very limited role of the Study of conditions and directions of spatial development in the spatial policy of the city of Łódz, as well as its small impact on the location of developers' activity. Decisions on building conditions are not always issued in accordance with its provisions.

\section{Discussion and conclusions}

In conclusion, the presented study allowed us to positively verify the hypothesis set out in the introduction stating that the study of conditions and directions of spatial development is of minor importance in the progression of developers' activity. Although the basic goal of spatial policy is the rational use of space to meet the specific needs of society, municipalities are not always able to achieve this goal. First of all, this results from legal regulations which, without making the provisions of the study of conditions and directions of spatial development binding, have meant that their role in urban development is insignificant. Decisions on building conditions are not always issued in accordance with the study, which is confirmed by the data presented in this article. It can even be argued that developers and other investors themselves have a great impact on shaping urban spatial policy, as demonstrated by the changes made in the Łódz Study from 2018, where some of the areas have been transformed, due to the fact that the developer had already built something in the given area. Therefore, the problem with discretionary issuing of $\mathrm{BC}$ decisions is still visible. This would perhaps be partially eliminated if Polish cities were more extensively covered with local plans. However, the costs of preparing such plans are very high, and the procedures for adopting them too long. Therefore, it seems that a better solution to increasing the rationality and efficiency of the spatial policy would be to introduce provisions that would prevent the authorities from issuing $\mathrm{BC}$ decisions contrary to the study's provisions into the Act on spatial planning and development. Otherwise, the fight against phenomena such as urban sprawl or urban chaos will still resemble the proverbial "tilting at windmills," and developers' investments will be located in places convenient for the developers themselves, and not appropriate from the point of view of the objectives and directions of spatial development assumed by the city.

\section{References}

Acheampong, R. (2018). Spatial Planning in Ghana. Origins, Contemporary Reforms and Practices, and New Perspectives. Springer.

Bednarowska, Z. (2015). Desk research - wykorzystanie potencjału danych zastanych w prowadzeniu badań marketingowych i badań społecznych (Desk research - exploiting the potential of secondary data in market and social research). Marketing i Rynek, 7(2015).

Brzeziński, C. (2013). Wybrane problemy planowania przestrzennego w Polsce (Selected problems of spatial planning in Poland). Acta Universitatis Lodzensis, Folia Oeconomica 289.

Bukhari, S. A. H. (2011), What is Comparative Study. Available at SSRN: https:// ssrn.com/abstract=1962328 or https://doi.org/10.2139/ssrn.1962328

Cullingworth, B., \& Nadin, V. (2006). Town and Country Planning in the UK (14th ed.). Routledge. https:// doi.org/10.4324/9780203004258

Foryś, I., \& Putek-Szeląg, E. (2015). The Influence Of Planning Decisions Regarding Land Evaluation Based On A Selected Local Real Estate Market. Real Estate Management and Valuation, 23(4), 62-73. https:// doi.org/10.1515/remav-2015-0037

Gorzym-Wilkowski, W. (2016). Planowanie przestrzenne jako czynnik kształtujący atrakcyjność rynkową nieruchomości - skuteczny i niebezpieczny (Spatial planning as a factor shaping the market attractiveness of real estate - effective and dangerous). Annales Universitatis Mariae CurieSkłodowska, Sectio B, LXXI. 
Hajduk S., \& Baran A. (2013). Planowanie przestrzenne gmin a proces inwestycyjny - zagadnienia problematyczne (Spatial planning of municipalities and the investment process - problematic issue), Studia Ekonomiczne, 2(62).

Izdebski, H., Nelic, A., \& Zachariasz, I. (2007). Zagospodarowanie przestrzenne. Polskie prawo na tle standardów demokratycznego państwa prawnego (Spatial development. Polish law against the background of democratic rule of law standards). Sprawne Państwo, Ernst\&Young.

NIK Łódź. (2011). Informacja o wynikach kontroli kształtowania i prowadzenia polityki przestrzennej na terenie miasta Eodzi (Information on the results of control of shaping and conducting spatial policy in the city of Łódź.

Saey P. (2002). Spatial planning as large-scale practical project: the problem of effective governance. Governance and geography, 3.

Stead D., \& Nadin, V. (2008). Spatial planning. Key instrument for development and effective governance with special reference to countries in transition. Technical Report, ECE.

Krajewska, M., Źróbek, S., \& Šubic-Kovač, M. (2014). The role of spatial planning in the investment process in Poland and Slovenia. Real Estate Management and Valuation, 22(2), 52-66. https:// doi.org/10.2478/remav-2014-0017

Nichersu, I., \& Iacoboaea, C. (2011). Systematic Spatial Planning. Theoretical and Empirical Researches in Urban Management, 6(2).

Ploegmakers, H., Beckers, P., \& Van der Krabben, E. (2018). The impact of planning intervention on business development: Evidence from the Netherlands. Urban Studies (Edinburgh, Scotland), 55(14), 3252-3273. https:// doi.org/10.1177/0042098017735011 PMID:30369645

Pluta, M. (2016). Spatial Planning In Poland in the Context of ISPIRE Rules and Amendment to the Spatial Planning and Development Act. Geomatics, Land Management and Landscape, 4.

Raźniak, P., \& Grochal, M. (2014), Wptyw zmiany miejscowych planów zagospodarowania przestrzennego na obrót nieruchomościami i ruch budowlany w gminie Dobczyce (Impact of changing local spatial development plans on real estate transactions and construction traffic in the Dobczyce commune), available at: https://www.researchgate.net/publication/264416444 (access: 12.10.2019).

Yakob, H., Yusof, F., \& Hamdan, H. (2012). Land use Regulations Towards a Sustainable Urban Housing: Klang Valley Conurbation. Procedia: Social and Behavioral Sciences, 68, 578-589. https://doi.org/10.1016/j.sbspro.2012.12.250

Studium uwarunkowań i kierunków zagospodarowania przestrzennego miasta Łodzi (Study of conditions and directions of spatial development of the city of Łódź), przyjęte uchwałą Rady Miasta Łodzi XCIX/1826/10, w dniu 24 października 2010 roku.

Studium uwarunkowań i kierunków zagospodarowania przestrzennego miasta Łodzi (Study of conditions and directions of spatial development of the city of Łódź), przyjęte uchwata Rady Miasta Uchwała $\mathrm{Nr}$ LXIX/1753/18_w dniu 28 marca 2018 roku.

ŚCIBOR, K. (2007). Ocena wybranych aspektów polskiego planowania przestrzennego w kontekście ZZOP (Assessment of selected aspects of Polish spatial planning in the context of ZZOP). Coastline Reports, 8, 212-224.

Ustawa $z$ dnia 27 marca 2003 roku o planowaniu i zagospodarowaniu przestrzennym (Act of 27 March 2003 on spatial planning and development), Dz. U. $2003 \mathrm{Nr} 80$ poz. 717

Uzasadnienie wynikajace $z$ art. 42 pkt 2 oraz Podsumowanie wynikajace $z$ art. 55 ust. 3 . Ustawy $z$ dnia 3 października 2008 roku o udostępnianiu informacji o środowisku i jego ochronie, udziale społeczeństwa w ochronie środowiska oraz ocenach oddziatywania na środowisko ( Dz.U z 2017 r. poz. 1405 z późniejszymi zmianami) do "Studium uwarunkowań i kierunków zagospodarowania przestrzennego miasta Łodzi" uchwalonego uchwata nr LXIX/1753/18 Rady Miejskiej w Łodzi z dnia 28 marca 2018 roku (Justification under article 42 point 2 and Summary resulting from art. 55 item 3 of The Act of 3 October 2008 on sharing information about the environment and its protection, public participation in environmental protection and environmental impact assessments (Journal of Laws of 2017, item 1405, as amended) to 'Study of conditions and directions of development the spatial city of Łódz' 'adopted by resolution No. LXIX /1753/18 of the City Council of Eódź of March 28, 2018), available at: https://mpu.lodz.pl/files/mpu/public/STUDIUM/obowiazujace/2018_SUIKZP_u_p.pdf (access: 17.10.2019). 